\title{
Pelatihan dan Pendampingan Penyusunan Pelaporan Keuangan Panti Asuhan Putri Aisiyah Kota Malang
}

\author{
Gina Harventy ${ }^{1)}$, Achmad Syaiful Hidayat Anwar ${ }^{2)}$ \\ 1) 2) Prodi Akuntansi, Universitas Muhammadiyah Malang \\ Email : gharventy@umm.ac.id ${ }^{1)}$, asyaiful@umm.ac.id ${ }^{2}$
}

\begin{abstract}
This community service activity aims to provide training and assistance in the preparation of financial reports at the Putri Asisiyah Orphanage in Malang City. Putri Aisyiyah Orphanage is one of the Amal Usaha Muhammadiyah (AUM) in Malang. The training and assistance in the preparation of financial reports are related to the problems faced by the orphanage manager, namely the activity of recording and reporting on orphanages that have not been carried out in an orderly manner and in accordance with reporting standards. Putri Aisiyah Orphanage has a business unit that has experienced significant development until now, so it is necessary to record and prepare good financial reports for the orphanage. So that administrators can evaluate the performance of operational activities of the orphanage and catering business units. The method of implementing the service program consists of socializing the importance of preparing financial reporting, training and assistance in the preparation of financial reports. The results of this service activity, the management and financial administration section of the Putri Aisiyah Orphanage have the skills (expertise) in making / compiling excel-based computerized financial reports and this service program has achieved the output of computational computational financial reporting work excel at the Putri Aisiyah Orphanage.

Keywords: Amal Usaha Muhammadiyah, Financial Statements, Financial Performance, Computing Applications
\end{abstract}

\begin{abstract}
Abstrak
Kegiatan pengabdian masyarakat ini bertujuan untuk melakukan pelatihan dan pendampingan penyusunan pelaporan keuangan Panti Asuhan Putri Asisiyah Kota Malang. Pelatihan dan pendampingan penyusunan pelaporan keuangan tersebut terkait permasalahan yang dihadapi oleh pengelola panti asuhan yaitu aktivitas pencatatan dan pelapora keuangan panti asuhan yang belum dilakukan secara tertib dan sesuai dengan standar pelaporan. Panti Asuhan Putri Aisiyah memiliki unit usaha yang hingga saat ini mengalami perkembangan yang cukup signifikan, sehingga diperlukan pencatatan dan penyusunan pelaporan keuangan yang baik bagi panti asuhan. Agar pengurus dapat melakukan evaluasi kinerja aktivitas operasional panti maupun unit bisnis catering. Metode pelaksanaan program pengabdian terdiri dari Sosialisasi pentingnya penyusunan pelaporan keuangan, pelatihan dan pendampingan penyusunan pelaporan keuangan. Hasil luaran kegiatan pengabdian ini pengurus dan bagian administrasi keuangan Panti Asuhan Putri Aisiyah telah memiiki skill (keahlian) dalam membuat/menyusun laporan keuangan terkomputerisasi berbasis excel dan program pengabdian ini mencapai luaran tersusunnya pengerjaan pelaporan keuangan komputasi berbasis excel yang dimiliki oleh Panti Asuhan Putri Aisiyah Kota Malang.
\end{abstract}

Kata kunci : Amal Usaha Muhammadiyah, Laporan Keuangan, Kinerja Keuangan, Aplikasi Komputasi 


\section{Pendahuluan}

Panti Asuhan Putri Aisyiyah Malang merupakan salah satu Amal Usaha Muhammadiyah dalam bidang jasa sosial yang didirikan pada tahun 1996. Kegiatan yang dilakukan diantaranya adalah pembinaan 32 anak asuh putri dari anak yatim, piatu, yatim piatu, terlantar dan tidak mampu dengan jenjang pendidikan yang berbeda. Terdiri dari 2 anak TK, 8 Anak SD, 10 anak SMP, 10 anak SMA, dan 2 anak yang sedang menempuh Pendidikan Tinggi. Sebagai salah satu cara pengembangan sumber daya dan sumber dana panti asuhan Aisiyah Putri memilihi bidang usaha catering kue basah dengan nama Panti Asuhan Putri Aisiyah Catering (PAP'A Catering).

\section{Usaha Panti Asuhan Putri} Aisyiyah Malang dimulai pada tahun 2000, bergerak di bidang pangan yaitu memproduksi kue basah. Yang bertujuan sebagai sumber dana operasional Panti Asuhan dengan memberdayakan anak-anak panti untuk membuat kue dan didampingi oleh pengelola panti asuhan. Kue basah yang diproduksi oleh Pap'a Catering memiliki kualitas rasa yang cukup baik. Terbukti banyaknya pelanggan yang terutama berasal dari Amal Usaha
Muhammadiyah lain yang berada disekitar Kota Malang atau pelanggan lain.

Perkembangan usaha Panti Asuhan yang semakin meningkat menuntut penertiban catatan atau pembukuan keuangan yang informatif dan sesuai dengan standar keuangan yang berlaku sesuai dengan jenis usahanya. Dan pengelola panti asuhan berkeinginan untuk menertibkan catatan/pembukuan panti asuhan. Permasalahan utama pengelola panti asuhan adalah aktivitas pencatatan dan pelaporan keuangan panti asuhan yang belum dilakukan dengan baik dan tertib. Sehingga menyebabkan tidak terdapat informasi bagaiman evaluasi kinerja keuangan dan informasi yang berguna sebagai alat pertanggung jawaban pengelola. Sehingga pengelola panti menginginkan administrasi pembukuan yang sederhana namun secara komprehensif menggambarkan seluruh aktivitas pengelolaan Panti Asuha dan Usaha catering. Harapannya pengelola panti asuhan dapat membuat dan melaporkan laporan keuangan yang sesuai dengan standar yang dapat digunakan sebagai informasi untuk pertanggung jawaban kinerja pengelolaan keuangan panti dan bidang usahanya. Selain itu digunakan sebagai alat mengevaluasi kinerja dan 
pengambilan keputusan untuk

peningkatan dan peluasan usaha panti

\section{Analisis Situasi}

a. Aspek Sumber Daya Manusia

Sumber daya yang digunakan dalam proses produksi catering sesuai dengan tujuan awal memberdayakan putriputri panti, tetapi seiring berkembangnya usaha panti SDM yang digunakan adalah Ibu-ibu di sekitar panti.

b. Aspek Kondisi Manajemen

Kondisi manajemen kurang tertata dengan baik yang meliputi pembagian tugas dan tanggung jawab, pengurus panti Asuhan khususnya bendahara atau bagian keuangan Panti Asuhan dan Pengelola unit usaha catering panti asuhan. Serta belum adanya pembagian job desc sesuai dengan tugas dan tanggung jawab masing-masing.

c. Aspek Kualitas Produk

Produksi kue basah Panti Asuhan Putri bagus, terbukti dengan semakin banyaknya pelanggan baik yang berasal dari Amal usahan Muhammadiyah atau pelanggan external

d. Aspek Pelaporan Keuangan

Panti Asuhan belum mampu melaksanakan pencatatan transaksi keuangan dengan benar dan tertib. Serta belum mampu menyusun informasi laporan keuangan dengan baik sesuai dengan standar pelaporan keuangan (PSAK).

Berdasarkan hasil informasi dan diskusi dengan pengelola Panti Asuhan Aisyiyah Putri, terdapat beberapa permasalahan dalam pelaporan keuangan usaha, yaitu:

1. Pencatatan transaksi keuangan yang belum rapi dan tertib.

2. Laporan keuangan masih sederhana dan belum sesuai dengan standar keuangan yang berlaku

3. Terdapat kesulitan dalam perhitungan perpajakan dan pengambilan keputusan bisnis.

4. Evaluasi efisiensi biaya belum pernah dilakukan karena keterbatasan informasi data biaya dan SDM

Berdasarkan hasil yang disepakati dengan mitra program pengabdian permasalahan mitra lebih difokuskan pada penyusunan laporan keuangan yang sesuai dengan standar pelaporan keungan yang berlaku.

Tujuan pokok pengabdian ini untuk menerapkan pembukuan dan pelaporan keuangan Panti Asuhan dan bidang usaha catering yang sesuai dengan standar pelaporan keuangan yang berlaku. Adapun tujuan khusus dan 
target luaran dari kegiatan pengabdian kepada masyarakat ini adalah sebagai berikut :

1. Meningkatnya pengetahuan dasar tentang pentingnya Pelaporan keuangan

2. Pembuatan Laporan keuangan untuk mengetahui berapa aset, liabilitas dan aset neto panti asuhan

3. Penertiban pencatatan untuk mengetahui arus kas masuk dan arus kas keluar yang dilakukan oleh panti dan bidang usahanya.

\section{Metode Pelaksanaan}

Berdasarkan pada analisis situasi dan permasalahan yang terjadi sebagaimana telah dibahas sebelumnya, maka keseluruhan aktivitas program akan dilaksanakan dengan menggunakan metode yang disesuaikan dengan tujuan yang diharapkan. Metode pendekatan yang dilakukan adalah pelatihan dan pendampingan. Adapun tahapannya sebagai berikut:

1. Sosialisasi program kerja, untuk berjalannya program ini secara efektif, jadwal pelaksanaan kegiatan program akan disusun sesuai dengan kesepakatan mitra.

2. Pembuatan aplikasi pelaporan keuangan berbasis Exell oleh tim pengabdi.
3. Penyampaian materi pada peserta secara tutorial dan metode ceramah. Metode ini dipilih untuk menyampaikan teori dan konsepkonsep pengetahuan dasar yang harus dikuasai oleh peserta yang meliputi bukti transaksi, pembuatan jurnal, dan pembuatan laporan keuangan (Laporan posisi keuangan dan laporan laba rugi)

4. Pendampingan

Setelah peserta memperoleh pengetahuan tentang konsepkonsep pengetahuan dasar yang harus dikuasai oleh peserta yang meliputi bukti transaksi, pembuatan jurnal, dan pembuatan laporan keuangan ( Laporan posisi keuangan dan laporan laba rugi), selanjutnya mitra mengimplementasikan pengetahuan yang didapatkan dalam usahanya. Selama proses pendampingan, dilakukan monitoring dan evaluasi pelaksanaan kegiatan oleh pelaksana pengabdian. 
- Membuat aplikasi excel untuk

Identifikasi Permasalahan

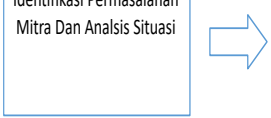

Penetapan Solusi Dan Alternatif Pemecahan $\square \quad$ Sosialisasi Progran Kerja Permasalahan Mitra
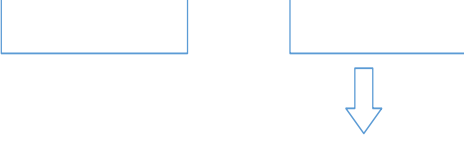

Pendampingan, Monitoring Dan Evaluasi Pelaksanaan Kegiatan Oleh Tim Pengabdian.

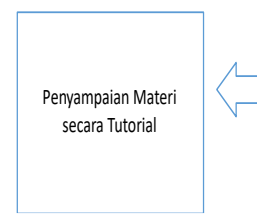

Pembuatan Aplikasi Pelaporan Keuangan Berbasis Exell
Gambar 1 : Alur Pelaksanaan Kegiatan

Untuk melaksanakan program pengabdian ini tugas dan tanggung jawab tim pengabdi didistribusikan sebagai berikut :

1. Ketua

- Bertanggung jawab terhadap pelaksanaan kegiatan pengabdian masyarakat.

- Menyusun draf proposal pengabdian kepada masyarakat dan melakukan diskusi kepada anggota.

- Memimpin dan mengkoordinir pelaksanaan pengabdian.

- Melakukan sosialisasi program pengabdian kepada Panti Asuhan

- Menyusun laporan kegiatan pengabdian

2. Anggota

- Berkoordinasi dengan ketua dalam menyusun draf proposal dan laporan akhir pelaporan keuangan panti asuhan

- Memberikan pelatihan penyusunan pelaporan keuangan panti asuhan

- Menyediakan kelengkapan dokumen yang diperlukan

3. Mahasiswa (Tim Pengabdian Masyarakat oleh Mahasiswa)

- Berkoordinasi dengan ketua dalam menyusun draf proposal dan laporan akhir program pengabdian

- Mempelajari petunjuk teknis penyusunan pelaporan keuanga berbasis komputasi

- Membantu ketua dan anggota pada saat pelaksanaan sosialisasi dan pelatihan dilokasi mitra

- Melakukan pendampingan rutin dalam penyusunan dan pelaporan keuangan Panti asuhan.

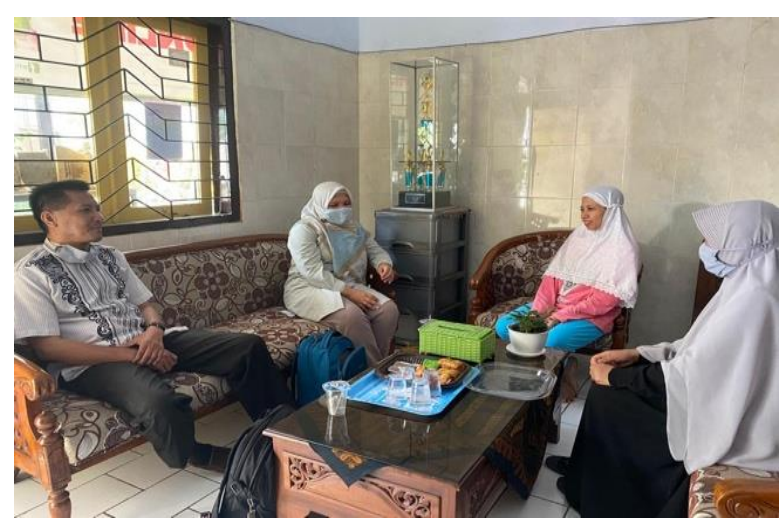

Gambar 2 : Tahap Sosialisasi 


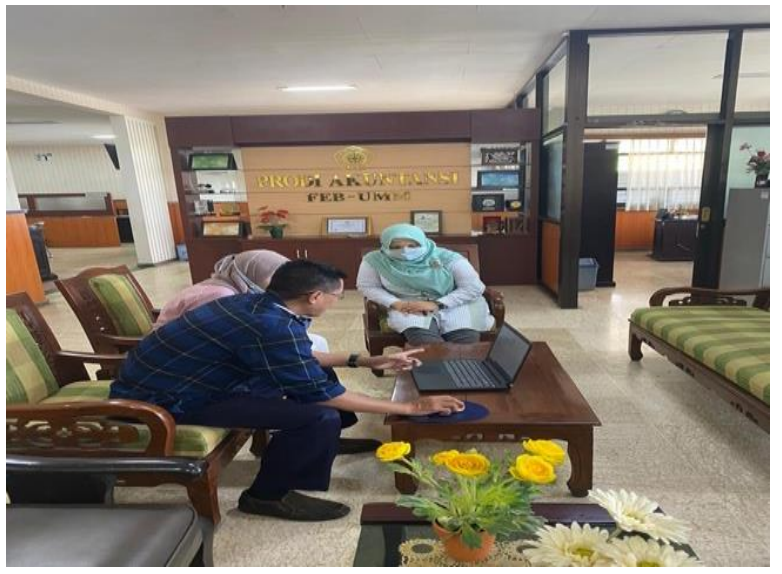

Gambar 3 : Tahap penyusunan Aplikasi Kompotasi penyusunan laporan keuangan berbasis Komputasi

\section{Hasil Dan Pembahasan}

Berdasarkan pelaksanaan pengabdian yang dilakukan oleh tim pengabdi bersama mitra Panti Asuhan Aisiyah Putri Dinoyo Malang, berikut ini disampaikan hasil yang diperoleh beserta pembahasannya : Hasil luaran dari kegiatan pengabdian masyarakat adalah Mitra khususnya dalam hal ini Pengurus serta bagian administrasi keuangan Panti Asuhan Putri Aisiyah telah memiliki skill (keahlian) dalam membuat pelaporan keuangan yang terkomputerisasi berbasis Excell untuk laporan operasional Panti Asuhan dan laporan operasional unit Catering. Pengabdian ini juga berhasil mencapai luaran tersusunnya pengerjaan pelaporan keuangan komputasi berbasis excel yang yang dimiliki oleh Panti Asuhan.

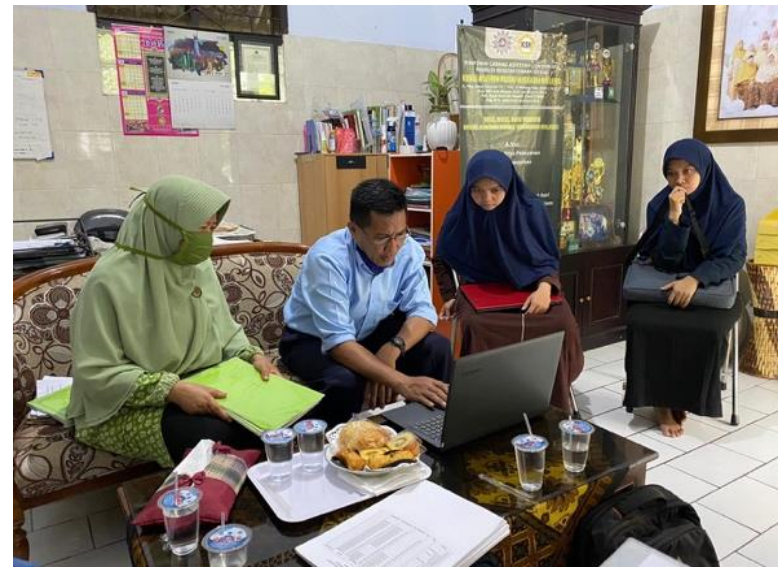

Gambar 4 : Tahap Pelatihan Penyusunan pelaporan keuangan terkomputerisasi

Beberapa hal yang diperoleh dari pelaksanaan pengabdian kepada masyarakat dapat diuraikan sebagai berikut :

a. Pengurus Panti yang terdiri dari Ketua, Bendahara, Penanggung jawab unit usaha catering dan staff bagian adimintrasi menyambut baik pelaksanaan pengabdian dan mendukung setiap tahapan kegiatan program pengabdian masyarakat ini.

b. Pendampingan pelaporan keuangan yang dilakukan oleh tim pengabdi berhasil membuat aplikasi pelaporan keuangan berbasis komputeriasi dengan program excel telah berhasil membuat laporan keungan pada bulan Oktober 2020. Dengan demikian Pengurus Panti Asuhan dapat mengetahui kinerja Panti dan Unit bisnis Catering. Diantaranya 
laporan Posisi keuangan (jumlah Aset, Kewajiban serta hutang) dan laporan laba rugi (pendapatan dan biaya yang dikeluarkan pada bulan Oktober 2020).

c. Dengan ketekunan dan antusias mitra dan tim pengabdi, pelaporan keuangan terkomputerisasi dapat diaplikasikan dengan baik serta dapat mempermudah dan dapat menertibkan pelaporan keuangan Panti asuhan.

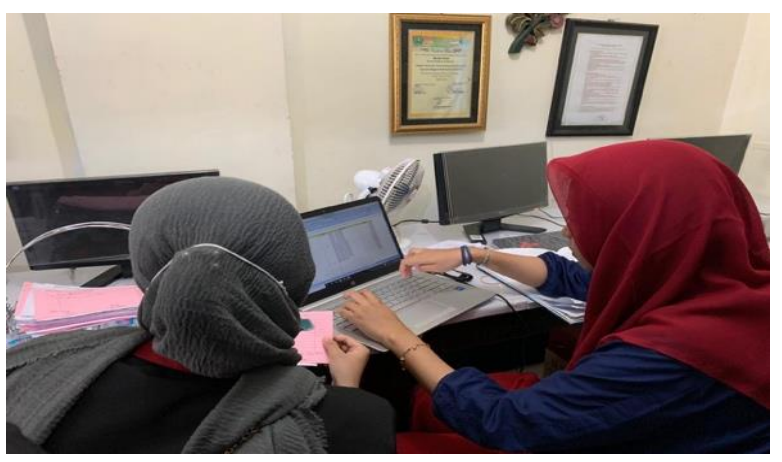

Gambar 5 : Tahap Pendampingan Penyusunan Pelaporan Keuangan berbasis Komputasi

Dengan demikian target luaran dari program pengabdian ini telah terpenuhi melalui diselenggarakannya rangkaian kegiatan pelatihan penyusunan laporan keuangan terkomputerisasi bagi Panti Asuhan Putri Aisiyah.

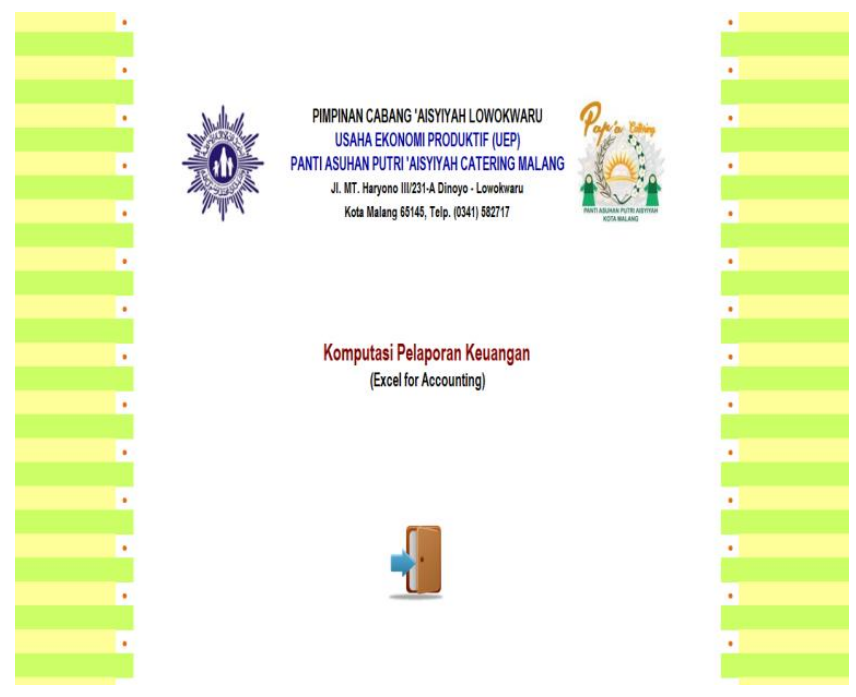

Gambar 6 : Halaman Beranda Aplikasi Excell

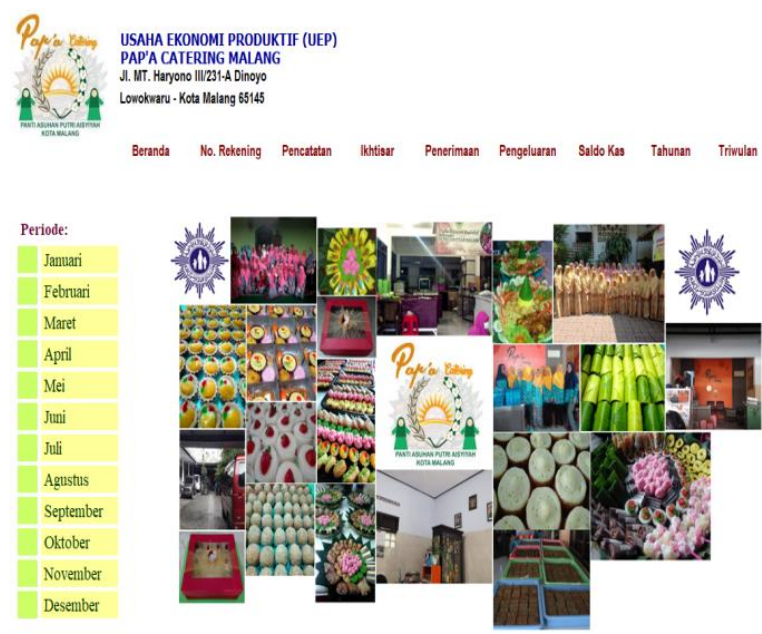

Gambar 7 : Menu Aplikasi

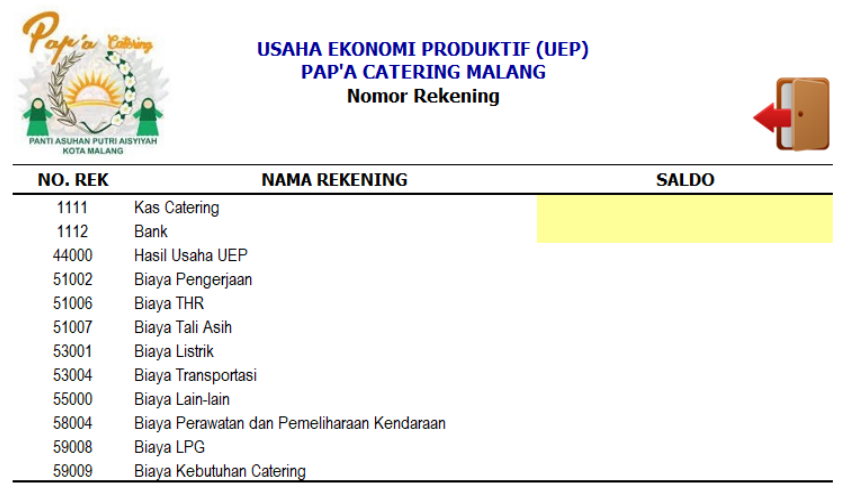

Gambar 8 : Daftar Akun dan Saldo Awal 


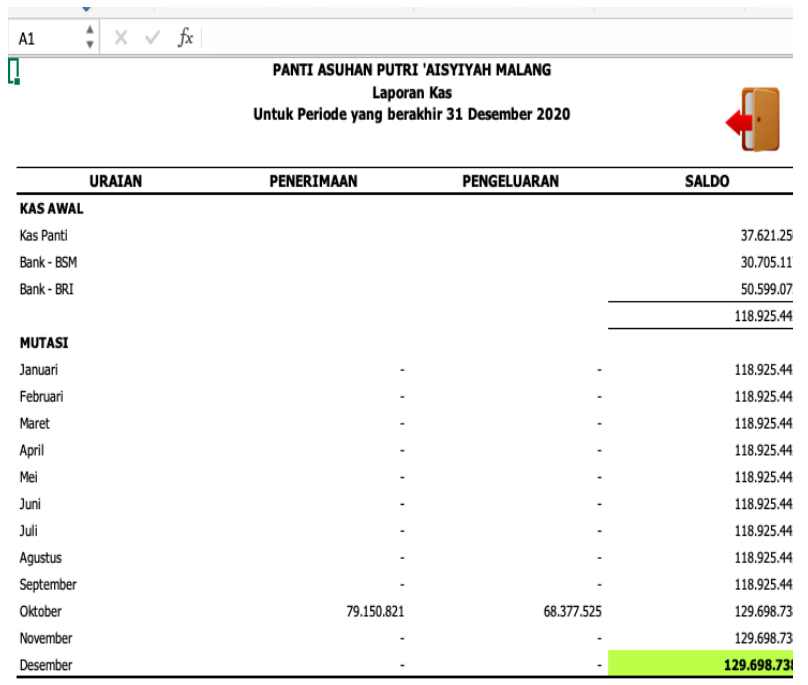

Gambar 9 : Laporan Arus Kas

\section{Simpulan}

Pelaksanaan

program

pengabdian kepada masyarakat dengan melakukan pelatihan dan pendampingan penyusunan pelaporan keuangan Panti Asuhan Putri Aisiyah ini berlangsung secara baik dan responsif. Hal tersebut terlihat dari dukungan dan antusias para Pengurus Panti Asuhan dalam mengikuti semua tahapan kegiatan mulai dari Sosialisasi, pelatihan sampai dengan kegiatan pendampingan penyusunan pelaporan keuangan. Luaran yang dicapai pada program pengabdian ini yaitu ketertataan dan ketertiban laporan keuangan Panti Asuhan dan Unit bisnis Catering, serta tersusunnya laporan keuangan berbasis Komputer pada
Panti Asuhan dan Unit Bisnis Catering Panti Asuhan Putri Aisiyah.

Pelaksanaan kegiatan pendampingan pelaporan keuangan perlu juga dilakukan untuk unit Koperasi khususnya pada Panti Asuhan Putri Aisiyah Dinoyo Malang, dan secara umum program pengabdian ini perlu dilakukan pada amal usaha lain yang ada di Wilayah Malang Raya

\section{Ucapan Terima Kasih}

Kami mengucapkan terima kasih kepada ketua Panti Asuhan Putri Aisyiyah kota Malang, DPPM-UMM, mahasiswa yang telah berpartisipasi pada kegiatan ini (Raisa dan Alfa) dan pihak lain yang juga turut mendukung terlaksananya kegiatan pengabdian kepada masyarakat.

\section{Daftar Pustaka}

Amani, T. 2018. "Penerapan SAKEMKM Sebagai Dasar Penyusunan Laporan Keuangan UMKM (Studi Kasus di UD Dua Putri Solehah Probolinggo)". ASSETS : Jurnal Ilmiah Ilmu Akuntansi, Keuangan dan Pajak, Vol., 2, No., 2, hlm: 1220.

Barus, I. N. E., A. Indrawati dan D. Solihin. 2018. "Implementasi SAK EMKM (Entitas Mikro, Kecil dan Menengah) Pada UMKM Borneo Food Truck Samarinda Community". Research Journal of Accounting and Business Management (RJABM), Vol., 2, No., 2, hlm: $176-183$. 
Cahyati, A. D., K. Mulyanti dan R. Setywasih. 2011. "Pemahaman dan Kesiapan UKM Dalam Implementasi SAK ETAP : Survey pada UKM di Bekasi”. JRAK Vol., 2, No.2, hlm: Hal. 19 - 27.

Hetika., N. Mahmudah. 2018. "Penerapan Standar Akuntansi Entitas Mikro Kecil Dan Menengah (SAK EMKM) dalam Menyusun Laporan Keuangan”. Jurnal Bisnis Terapan, Vol., 2, No., 1, hlm: 81-104.

Ikatan Akuntan Indonesia. 2016. Press Release: IAI Siapkan Standar Akuntansi agar EMKM Capai Literasi Keuangan. [www.iaiglobal.or.id]. diakses tanggal 16 November 2018.

Ikatan Akuntan Indonesia. 2016. Standar Akuntansi Keuangan: Entitas Mikro, Kecil, dan Menengah. DSAK IAI: Jakarta.

Kementrian Koperasi dan Usaha Kecil dan Menengah. 2018. Perkembangan Data Usaha Mikro, Kecil, dan Menengah (UMKM) dan Usaha Besar (UB) tahun 2012-2017. [www.depkop.go.id]. diakses tanggal 16 November 2018.

Ningtyas, J. D. A. 2017. "Penyusunan Laporan Keuangan UMKM
Berdasarkan Standar Akuntansi Keuangan Entitas Mikro, Kecil dan Menengah (SAK-EMKM) (Study Kasus Di UMKM Bintang Malam Pekalongan)". Riset \& Jurnal Akuntansi, Vol., 2, No., 1, hlm: 1117.

Prajanto, A., dan I. Septriana. 2018. "Implementasi Penerapan SAK EMKM serta Dampaknya pada Kualitas Pelaporan Keuangan UMKM (Studi Kasus Pada UMKM Se Kota Semarang)". Aset, Vol., 20, No., 2, hlm: 79-89.

Tatik,. 2018. "Implementasi SAK EMKM

(Standar Akuntansi Keuangan Entitas Mikro Kecil Dan Menengah) Pada Laporan Keuangan UMKM (Studi Kasus Pada UMKM XYZ Yogyakarta)". Jurnal Relasi, Vol., XIV, No., 2, hlm: 1-14.

Undang-undang No. 20 tahun 2008 tentang Usaha Mikro, Kecil, dan Menengah.h. DSAK IAI: Jakarta. 